\title{
To the readers of the IJMBOA on its birthday: will molecular biology reshape our near future on 2050 $\&$ beyond as we are picking up the needle from the straw?
}

\section{Editorial}

This Editorial aims to address the philosophical scientific question with respect to some of the historical development in the field and gearing up toward the future which is being expected to be reshaped by the gene therapy as the latest platform of molecular biology. Therefore, the philosophical focus on our mission we are addressing in our new journal of IJMBOA is to share the international research community to build up progressively the concept of molecular biology for the near future and beyond. Obviously this looks like as if we are looking on the needle in the straw. Despite the fact that molecular biology has originated on 1930's, the importance of its subsequent platform has been built up fairly rapidly on genomics \& beyond. Over the past 50 decades, several historiographical reviews have documented the development of molecular biology. ${ }^{1-5}$ The collective information outcome built of geneticists, physicists, and structural chemists has revealed the nature of inheritance as early as Thomas Hunt Morgan \& his former student Hermann J. Muller have recognized that the "gene as a basis of life". ${ }^{6,7}$ Then, Alfred Hershey, Martha $\mathrm{C}^{8}$ used phage viruses to confirm that the genetic material transferred from generation to generation was DNA and not proteins. The molecular biology term began in 1953, with Watson J, Crick's $\mathrm{F}^{9,10}$ discovery of the double helical structure of DNA \& he began calling himself a molecular biologist.

In the 1970s, many of the leading molecular biologists have concentrated their research on genomics. The discovery of the DNA sequencing by Frederick Sanger together with Alan Coulson on $1975^{11,12}$ was the turn point of the modern molecular biology which has led us to the currently used Next-Generation sequencing (NGS).In the mid 1980s, after the development of sequencing techniques, the United States Department of Energy (DoE) launched a project to sequence the human genome known as Human Genome Project (HGP), which then completed on April 14, 2003. These developments in genomics and post-genomics have sparked a number of philosophical questions about molecular biology leading molecular biologist concentrate on epigenetic, behavioral genetics, molecular developmental biology \& gene programing, population genetics \& epidemiology.

These historical accumulative integrated developments of molecular biology \& the availability of such huge data of bioinformatics on human genomics have led recently to a worldwide growing interest on gene therapy as the most sustainable therapeutic approach for cancers as well as genetic diseases. Currently, the research outcomes, using the latest technology such as Next-Generation Sequencing and Biochip Microarray, have shown conclusively that the epidemiology of cancers is correlated to the genealogy and ethnicity of the populations clusters around the world.

Therefore, many research institutions and pharmaceutical industry around the world are concentrating now a day son the genealogical
Volume I Issue I - 2016

\author{
Ihsan Ali Khlaif Mahasneh \\ Department of Biotechnology, Faculty of Science, University of \\ Sharjah, UAE
}

Correspondence: Ihsan Ali Khlaif Mahasneh, Department of Biotechnology, Faculty of Science, University of Sharjah, UAE, Email imahasneh@sharjah.ac.ae

Received: September 28, 2016 | Published: September 30, 2016

profiling of both cancers \& the epidemiological genetic disease among the worldwide populations which will provide a valuable data to enhance diagnosis, therapy and thus the overall managements of the familial cancer disease in the region. The availability of the huge bioinformatics data deposited in the International Gene/Banks/DDBJ/ EMBL/NCBI and the International Heliotype Reference Database (YHRD) will definitely formulate the future of the molecular biology in general and more particularly the human kind. Therefore, the use of the vigorously growing up technology of gene therapy is going to be investable and definitely will re shape the near future of human kind health care particularly among many nations where we have a high frequency on endemic genetic disease due to the high rate of consanguinity (relative marriages).Our International Journal of Molecular Biology Open Access (IJMBOA) with its international caliper and scope, we will cover a wide range of research lines from cloning, sequencing \& microarrays to stem cell bioinformatics. Finally, the journal will be committed to continue its mission to focus as with the international research community to achieve the clearest possible scientific picture on the coming up horizon of molecular biology for a better life of human kind in particular. The journal cordially invites Research Articles, Review Articles, Short Communications, Case Reports, Mini- Reviews, Opinions, Letter to Editors etc. for the latest ongoing and future research. The journal will continue to acts to serve research community and public.

\section{Acknowledgements}

None.

\section{Conflict of interest}

Author declares that there is no conflict of interest.

\section{References}

1. Watson JD. Molecular Biology of the Gene. New York: W.A. Benjamin; 1965.

2. Watson JD. The Double Helix. New York: New American Library; 1968. 
3. Watson JD. Genes, Girls, and Gamow. New York: Knopf; 2002.

4. Watson JD. Avoid Boring People: Lessons from a Life in Science. New York: Alfred A Knopf; 2007.

5. Abir-Am P. Themes, Genres and Orders of Legitimation in the Consolidation of New Scientific Disciplines: Deconstructing the Historiography of Molecular Biology. Hist Sci. 1985;23(59 pt1):74-117.

6. Morgan, Thomas H. The Theory of the Gene. USA: Yale University Press; 1926.

7. Muller HJ. Artificial transmutation of the gene. Science. 1927;66(1699):84-87.
8. Hershey AD, Chase M. Independent Functions of Viral Protein and Nucleic Acid in Growth of Bacteriophage. J Gen Physiol. 1952;36:39-56.

9. Watson JD, Crick FH. Molecular structure of nucleic acids; a structure for Deoxyribose nucleic acid. Nature. 1953;171(4356):737-738.

10. Watson JD, Crick FH. Genetical Implications of the Structure of Deoxyribonucleic Acid. Nature. 1953;171(4361):964-967.

11. Sanger F, Nicklen S, Coulson AR. DNA sequencing with chainterminating inhibitors. Proc Natl Acad Sci USA. 1977;74(12):5463-5467.

12. Sanger, Frederick. Sequences, Sequences, and Sequences. Annual Review of Biochemistry. 1988;57:1-29. 